\title{
Review
}

\section{Pathophysiological Function of Adrenomedullin and Proadrenomedullin N-Terminal Peptides in Adrenal Chromaffin Cells}

\author{
Hideyuki KOBAYASHI, Toshihiko YANAGITA, Hiroki YOKOO, and Akihiko WADA
}

\begin{abstract}
Adrenomedullin (AM) and peptides of the proadrenomedullin N-terminal 20 peptide (PAMP20) family are multifunctional peptides abundantly expressed in the adrenal medulla. These peptides are released by regulated exocytosis along with catecholamines upon stimulation of adrenal chromaffin cells. They are also released gradually during culture, and this release is stimulated by a $3^{\prime}, 5^{\prime}$-cyclic adenosine monophosphate (cAMP)dependent pathway. The expression and release of AM increase under hypoxia in chromaffin cells. The expression of AM in pheochromocytoma PC12 cells is reduced during neuronal differentiation with nerve growth factor. On the other hand, PAMP20 and PAMP12 suppress catecholamine release and synthesis by interfering with nicotinic cholinergic receptors. AM increases blood flow in the adrenal gland, and causes a gradual release of catecholamine, but does not modify regulated exocytosis upon the stimulation of cells. Current data indicate that the expression of these peptides is regulated by intracellular signaling pathways, and changes under various physiological and pathological conditions. AM and PAMP20 family peptides have distinct physiological functions. PAMP20 and PAMP12 are endogenous peptides that modulate chromaffin cell function in an autocrine manner, whereas AM may mainly regulate vascular cell function in a paracrine manner. (Hypertens Res 2003; 26 (Suppl): S71-S78)
\end{abstract}

Key Words: adrenomedullin, proadrenomedullin N-terminal peptides, chromaffin cells, cholinergic receptors, hypoxia

\section{Introduction}

Adrenal medullary cells are endocrine cells embryologically derived from the neural crest, which synthesize and release catecholamines. They are composed of adrenaline chromaffin cells and noradrenaline chromaffin cells with minor populations of small intensely fluorescent cells and ganglionic neurons (1). Both adrenaline and noradrenaline chromaffin cells express catecholamine synthesizing enzymes, tyrosine hydroxylase (TH) and dopamine $\beta$-hydroxylase (DBH). Adrenaline cells, but not noradrenaline cells, have phenylethanolamine-N methyl transferase (PNMT), an en- zyme that methylates noradrenaline into adrenaline.

Acetylcholine liberated from splanchnic nerve terminals induces regulated exocytosis of constituents of chromaffin granules in $\mathrm{a} \mathrm{Ca}^{2+}$-dependent manner. The cholinergic receptor subtypes responsible for catecholamine release differ among species; in cows, nicotinic but not muscarinic stimulation induces catecholamine release (2), while in rats and dogs, both nicotinic and muscarinic stimulation induce catecholamine release $(3,4)$. In addition, the stimulation of cholinergic receptors increases catecholamine synthesis via the activation of $\mathrm{TH}$, the rate limiting enzyme of catecholamine synthesis (5).

In addition to catecholamines, chromaffin cells produce a

From the Department of Pharmacology, Miyazaki Medical College, Miyazaki, Japan.

This work was supported in part by the Grants-in-Aids for Scientific Research on Priority Areas and for the 21st Century COE Program (Life Science) from the Ministry of Education, Culture, Sports, Science and Technology, Japan, and a Grant for Special Research Project from Miyazaki Medical College. Address for Reprints: Hideyuki Kobayashi, Ph.D., Department of Pharmacology, Miyazaki Medical College, 5200 Kihara, Kiyotake, Miyazaki 889-1692, Japan. E-mail: hkobayas@ post.miyazaki-med.ac.jp

Received August 5, 2002; Accepted in revised form September 17, 2002. 
variety of peptides including chromogranins, opioid peptides and neuropeptide $\mathrm{Y}(6,7)$, which have unique functions such as regulating catecholamine release (8), regulating antibacterial activity (9), sorting peptides from the trans-Golgi network to dense core secretory granules $(10)$, and regulating cell adhesion (11).

Catecholamines and other constituents in the chromaffin granules from chromaffin cells are released by pathophysiological stress. Hypoglycemia, hemorrhage, cold exposure or hypoxia causes exocytotic release directly via activation of chromaffin cells, as well as indirectly via activation of the preganglionic sympathetic fibers innervating chromaffin cells (1).

On the other hand, adrenomedullin (AM) is a hypotensive peptide that was originally identified in human pheochromocytoma by monitoring of its action on $3^{\prime}, 5^{\prime}$-cyclic adenosine monophosphate (cAMP) in platelets (12). The AM level in plasma is altered in various diseases; for example, it is increased in patients with hypertension and normalized by anti-hypertensive therapy, indicating that AM is involved in protection against injury occurring in various pathological conditions $(13,14)$. The precursor of AM, the preproAM gene, also produces another hypotensive peptide, the proadrenomedullin N-terminal 20 peptide (PAMP20) (15). However, the mechanisms of action of these peptides are different. In the perfused rat mesenteric arteries, AM directly dilates vascular smooth muscle via receptor that reacts with calcitonin gene-related peptide (CGRP) (16), whereas PAMP20 inhibits noradrenaline release from sympathetic nerve endings, resulting in vasodilatation (17).

These peptides are produced not only in pheochromocytoma, but also in almost all organs of the body, and regulate a variety of cell functions (18). Because, among normal tissues, these peptides are most abundantly present in the adrenal medulla, this review focuses on the regulation of expression of the AM and PAMP20 family as well as those functions under pathological states in adrenal chromaffin cells.

\section{Expression and Release of AM and PAMP20 from Adrenal Chromaffin Cells}

Studies have shown that the levels of immunoreactive (ir)AM and ir-PAMP20 in the human adrenal medulla are more than 10 times higher than the already high concentrations in the atrium or pancreas (19-21). AM in the adrenal medulla is synthesized by processing from preproAM via proAM, and the major ir-AM found in human adrenal medulla is mature AM.

Although AM and PAMP20 are produced from the same gene, the level of ir-PAMP20 is lower than that of ir-AM in the adrenal medulla $(22,23)$. This finding led us to seek novel PAMP20-related peptides in the adrenal medulla. By using an antibody recognizing the C-terminal structure of PAMP20, it was found that a high level of PAMP12, a 12 amino acid peptide identical to PAMP20 at amino acids 9-20, was present in pigs and cows $(24,25)$. In addition, a considerable level of PAMP16, a peptide identical to PAMP20 at amino acids 5-20, was identified in the bovine adrenal medulla (24). Therefore, PAMP20, PAMP12 and PAMP16 constitute a family of PAMP peptides.

ir-AM, ir-PAMP20 and catecholamines are released by stimulation of nicotinic cholinergic receptors of cultured bovine adrenal chromaffin cells with similar concentrationand time-dependent curves $(26,27)$. The molar ratio among ir-AM, ir-PAMP20 and catecholamine release has been shown to be equivalent to the ratio found in the cells $(26$, 27). In addition, the elution patterns on high performance liquid chromatography (HPLC) for ir-AM and ir-PAMP20 released into the medium are the same as those found in chromaffin cells $(24,26,27)$. Thus, AM and PAMP20 are stored in and released from chromaffin cells by exocytosis along with catecholamines.

ir-AM and ir-PAMP20 are also released gradually during culture of the bovine chromaffin cells (28). This gradual release of ir-AM and ir-PAMP was increased by a membrane permeable analog of cAMP, dibutyryl cyclic AMP (dbcAMP). The release of these peptides by dbcAMP was similar to that of catecholamines and chromogranin B, a marker peptide contained in chromaffin granules. In addition, AM mRNA was decreased by dbcAMP. These changes induced by dbcAMP were attenuated by H89, an inhibitor of cAMPdependent protein kinase, indicating that a cAMP-dependent protein kinase pathway stimulates the gradual release of these peptides via an exocytotic mechanism and decreases their synthesis via the reduction of their transcription level.

Although adrenal medulla synthesizes and releases high levels of AM and PAMP20, this tissue is unlikely to be the major source for these peptides in the blood. The AM concentration in the adrenal vein is not different from that in the aorta, and the AM level in the plasma is not higher in patients with pheochromocytoma, whose plasma catecholamine level is markedly elevated (29). In addition, it has been reported that plasma AM levels were not changed significantly in patients with insulin-induced hypoglycemia, where plasma adrenaline levels were significantly increased (30). Therefore, these peptides released from the adrenal medulla are unlikely to act as circulating hormones.

Vascular endothelial and smooth muscle cells in various tissues produce and release a high level of $\operatorname{AM}(31,32)$, and these cells may be the major source of plasma AM. In this regard, it is interesting to note that, in rats, AM production by brain endothelial cells is very high, and AM plasma concentration in the jugular vein is $50 \%$ higher than that in the vena cava (33).

Hypoxia occurs in various physiological and pathological conditions, such as embryogenesis, labor, wound repair and carcinogenesis, and causes various responses, including activation of the sympathetic nervous system, hormone release and activation of gene expression. Under hypoxia, oxygen 
(a)

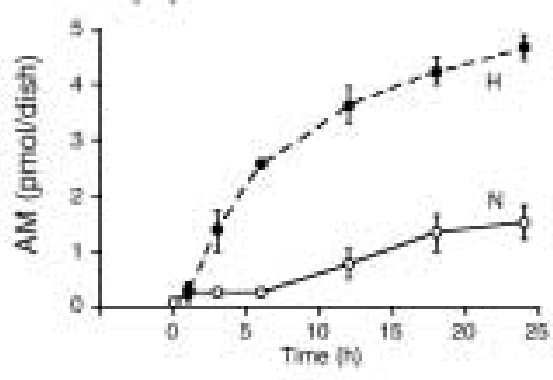

(b)

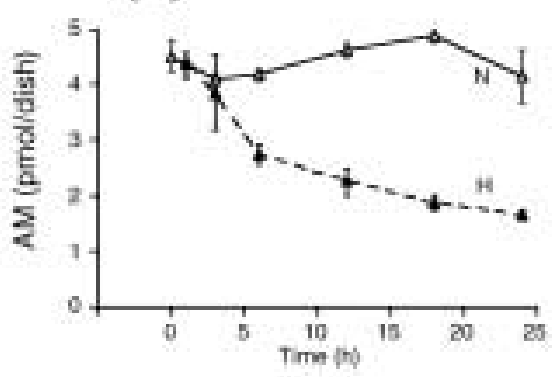

(c)

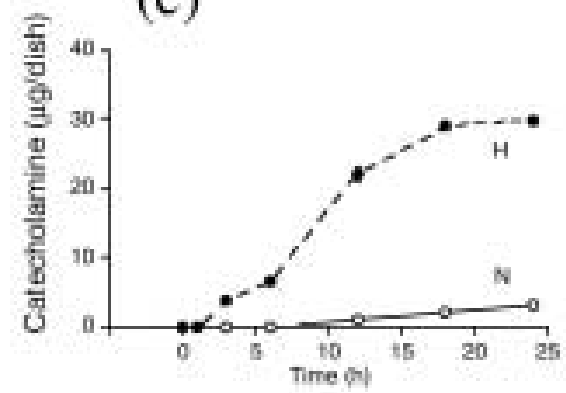

(d)

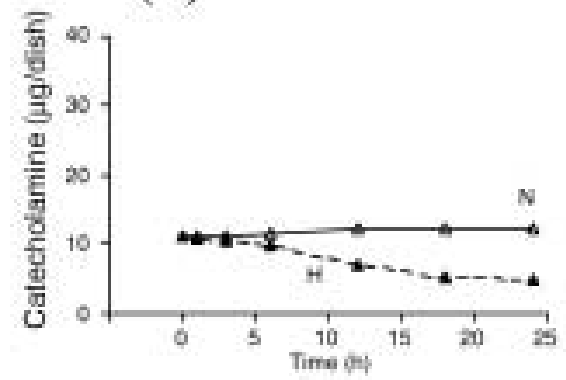

(e)

AM

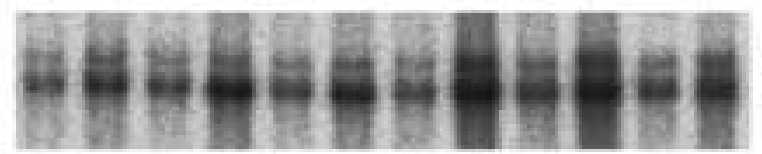

GAPDH

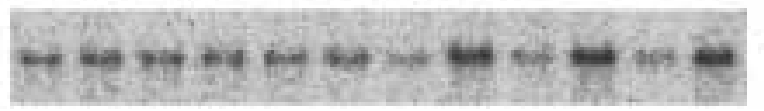

$1.1 \mathrm{~kb}$

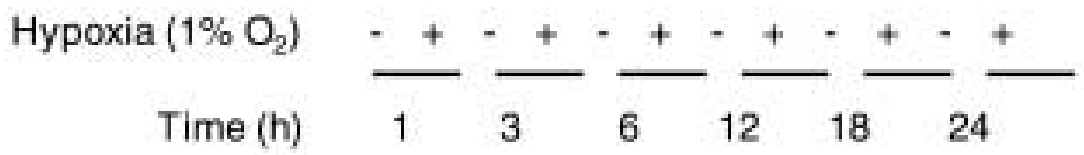

Fig. 1. Increase in the release and expression of AM by hypoxia in cultured bovine chromaffin cells. Cells $\left(4 \times 10^{6}\right.$ cells/dish) were cultured under normoxic $(\mathrm{N})\left(20 \% \mathrm{O}_{2}\right)$ or hypoxic $(\mathrm{H})\left(1 \% \mathrm{O}_{2}\right)$ conditions for the periods indicated on the horizontal axis, and $\operatorname{ir}-A M(a, b)$ and catecholamines $(c, d)$ in the medium $(a, c)$ and cells $(b, d)$ were measured by radioimmunoassay and by HPLC coupled with electron chemical detection, respectively. Data are the mean \pm SEM of three independent experiments. The AM mRNA level in the cells cultured under hypoxia for the indicated times was analyzed by Northern blotting (e). Poly $A^{+}$RNA prepared from $200 \mu \mathrm{g}$ of total RNA was separated by $2 \%$ agarose gel, transferred to a nylon membrane and hybridized with a probe for AM or glyceraldehyde 3-phosphate dehydrogenase (GAPDH). AM mRNA was identified as a major band of $1.6 \mathrm{~kb}$ with a band of $2.5 \mathrm{~kb}$. The mRNA level increased 4-fold under hypoxic condition at $12 \mathrm{~h}$ of hypoxia.

sensitive mechanisms activate gene expression of a variety of types of proteins, including differentiation factors, growth factors, enzymes and transporters such as erythropoietin, glucose transporter, heme oxygenase 1, vascular endothelial growth factor (VEGF), endothelin, and heat shock proteins $(34,35)$. Therefore, in a recent study, we examined whether AM expression changed under a hypoxic condition in bovine chromaffin cells.

Hypoxia $\left(1 \% \mathrm{O}_{2}\right)$ increased the accumulation of ir-AM in the medium, whereas reciprocally decreased their cellular content (Fig. 1). The catecholamine level in the medium increased, whereas the cellular content of catecholamine decreased under hypoxia, indicating that hypoxia caused exocytotic release of AM along with catecholamine. The total amount of AM in the medium plus that in cells increased under hypoxia. The AM mRNA level increased 4-fold under hypoxia, indicating that hypoxia stimulated AM release and synthesis via an increase of its transcript level.

The adrenal gland is a highly vascularized organ, and its blood flow is regulated by autonomic innervation as well as 
(a)

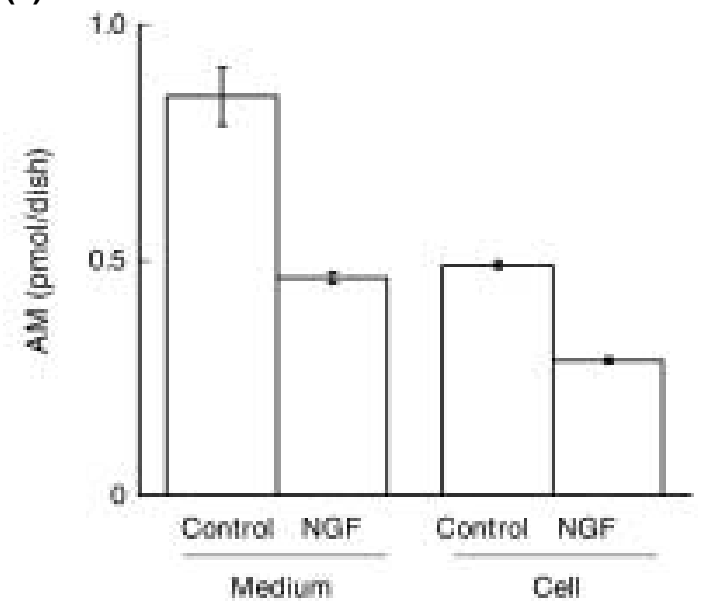

(b)

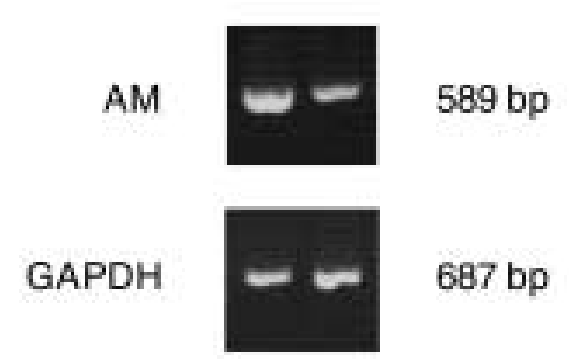

Fig. 2. Decrease in AM expression in PC12 cells differentiated by NGF. PC12 cells $\left(1 \times 10^{6}\right.$ cells/dish $)$ were cultured in the absence or presence of $2.5 \mathrm{~s} \mathrm{NGF}(50 \mathrm{ng} / \mathrm{ml})$ for 2 days, and $\operatorname{ir}-A M(a)$ was measured by radioimmunoassay. Note that the differentiation by NGF reduced ir-AM level both in the medium and cells. mRNA levels were analyzed by $R T$-PCR using primers amplifying $589 \mathrm{bp}$ of rat AM sequence (145-733 of D15069) and $687 \mathrm{bp}$ of rat GAPDH sequence (207-893 of M17701).

by nitric oxide, endothelin, and many other factors. Since AM increased blood flow in the isolated adrenal gland in situ and in the intact adrenal gland in vivo, this increased release by hypoxia may play a role in protecting against hypoxia of the adrenal gland. In addition, AM may facilitate the transport of catecholamines and other substances released from the adrenal gland to systemic circulation under hypoxia (36, 37).

The expression of AM changes during cell differentiation. In contrast to adrenal chromaffin cells, most neurons express little $\operatorname{AM}(21,38)$. Therefore, we next examined how AM expression is regulated by neuronal differentiation using rat pheochromocytoma PC12 cells (Fig. 2). When PC12 cells were differentiated by nerve growth factor (NGF), AM accumulation in the cell and medium decreased with neuronal differentiation. The AM mRNA level was also decreased by NGF, indicating that NGF decreases the expression of AM with neuronal differentiation.

\section{Receptors for AM and PAMP20 in Adrenal Chromaffin Cells}

The data about receptors for AM and PAMP20 in adrenal chromaffin cells are not consistent. We have not been able to detect the $\left[{ }^{125} \mathrm{I}\right] \mathrm{AM}$ - or $\left[{ }^{125} \mathrm{I}\right] \mathrm{PAMP}-$ binding sites in bovine adrenal chromaffin cells or membrane fraction (39). In addition, $\left[{ }^{125} \mathrm{I}\right] \mathrm{AM}$-binding sites could not be detected in the rat adrenal gland, in spite of the presence of a high level of $\left[{ }^{125} \mathrm{I}\right] \mathrm{AM}$-binding sites in the membrane fraction of various tissues (40).

However, the binding sites for [ $\left.{ }^{125} \mathrm{I}\right] \mathrm{AM}$ have been detected by autoradiography in the rat adrenal medulla, and have been shown to be displaced by low concentrations of AM, AM[22-52] or CGRP[8-37] with similar potency, suggesting that $\mathrm{AM}$ reacts with receptors which recognize both $\mathrm{AM}$ and CGRP (41). An abundance of [ $\left.{ }^{125} \mathrm{I}\right] \mathrm{AM}$-binding sites have also been detected in the membrane fraction of the rat adrenal medulla (42). These sites were of high affinity with a $K_{\mathrm{d}}$ of $3.64 \mathrm{nmol} / 1$ and were displaced only by AM, but not by CGRP, indicating that the receptors were specific to AM. Thus, the affinity and selectivity were different among these studies.

To date, three putative $\mathrm{G}$ protein-coupled receptors for AM have been cloned: L1 as an AM selective receptor (43); RDC-1 as a CGRP receptor that also reacts with AM (44); and calcitonin receptor-like receptor (CRLR), which requires co-expression of receptor-activity-modifying protein (RAMP) for its receptor activity (45). The expression of CRLR with RAMP2 or RAMP3 produces an AM receptor, while the combination of CRLR and RAMP1 produces a CGRP receptor (45). However, the identity of L1 and RDC-1 as receptors for AM or CGRP has been questioned $(46,47)$. According to the CRLR-RAMP hypothesis, the difference of the selectivity to the binding sites might become clear by studying the expression of each RAMP in human and rat chromaffin cells.

Renshaw et al. have detected the presence of CRLR and $\mathrm{L} 1$ and their respective mRNAs in the rat adrenal medulla (42). Both CRLR and L1 were expressed in DBH-positive cells (catecholamine-producing cells), but not in PNMT-positive cells (adrenaline cells), suggesting that AM receptors are only found in noradrenaline cells. Since AM staining was less intense in PNMT-negative cells, adrenaline cells may be a more significant source of AM than noradrenaline cells (48). Renshaw et al. suggest that AM acts as a paracrine regulator, that is, AM produced mainly in adrenaline cells may act on noradrenaline cells (42).

Iwasaki et al. showed the presence of [ $\left.{ }^{125} \mathrm{I}\right] \mathrm{PAMP}$-binding sites in the membrane fraction of various rat tissues (49). The molecular weight of PAMP-binding sites, as determined by cross-linking [ $\left.{ }^{125} \mathrm{I}\right]$ PAMP to the membranes of adrenal glands, was $90 \mathrm{kDa}(49)$. Hinson et al. also showed the presence of the high affinity and high capacity $\left(K_{\mathrm{d}}: 4.9 \mathrm{nmo} / \mathrm{l}\right)$ 
$\left[{ }^{125} \mathrm{I}\right]$ PAMP-binding sites in the membrane of the rat adrenal medulla (50). [ $\left.{ }^{125} \mathrm{I}\right]$ PAMP-binding sites have also been demonstrated in the human adrenal medulla by autoradiography (51), and these sites were shown to be displaced by low concentrations (IC50 value of nanomolar order) of PAMP20 and PAMP[12-20], but not by AM (52). However, these high-affinity binding sites may not correlate with the regulated exocytosis and synthesis of catecholamines, in which the $\mathrm{IC}_{50}$ value for PAMP20 was of micromolar order $(24,26)$.

\section{Functions of AM, PAMP20 and PAMP12 in Adrenal Chromaffin Cells}

$\mathrm{AM}$, at nanomolar concentrations, has been shown to gradually release a small amount of catecholamine in human and rat adrenal medulla slices $(41,53)$. This AM-induced catecholamine release was abolished by H-89 $(41,53)$, suggesting that the gradual release of catecholamine in human and rat adrenal medullary slices following AM treatment may be mediated via a cAMP-dependent protein kinase pathway.

In our previous study, however, we were unable to detect the effect of AM on catecholamine release from the bovine adrenal chromaffin cells (39). Houchi et al. also failed to detect the effect of AM on intracellular free $\mathrm{Ca}^{2+}\left(\left[\mathrm{Ca}^{2+}\right]_{\mathrm{i}}\right) \mathrm{lev}-$ els or catecholamine release from these cells, although AM stimulated the efflux of ${ }^{45} \mathrm{Ca}^{2+}$ from cells through its stimulatory effect on membrane $\mathrm{Na}^{+} / \mathrm{Ca}^{2+}$ exchanger in cultured bovine adrenal chromaffin cells (54).

In addition, neither AM nor AM[22-52] had any effect on either basal catecholamine release, catecholamine release induced by electrical stimulation of the splanchnic nerve, or catecholamine release induced by acetylcholine injection into the phrenico-abdominal artery of dogs, indicating that AM does not play a significant role in the regulated exocytosis of catecholamine in adrenal chromaffin cells (55).

AM plays a role in the prevention of apoptosis of many cell types, including vascular endothelial cells, but in our previous study we did not observe a suppressive effect of AM on the apoptosis of PC12 cells caused by serum deprivation (unpublished data). Therefore, these data may suggest that the role of AM in chromaffin cell function is not extensive, though AM may play a role in the regulation of vascular tone to facilitate transport of hormones released in the adrenal gland to the systemic circulation and to protect from ischemic injury of the gland.

On the other hand, PAMP20 and PAMP12 modify the regulated exocytosis of catecholamine from the cells. In cultured bovine adrenal chromaffin cells, PAMP20 and PAMP12, with an $\mathrm{IC}_{50}$ of about $0.1 \mu \mathrm{mol} / 1$, inhibited ${ }^{22} \mathrm{Na}^{+}$ influx caused by the stimulation of nicotinic cholinergic receptors in a non-competitive manner, thereby reducing ${ }^{45} \mathrm{Ca}^{2+}$ influx via voltage-dependent $\mathrm{Ca}^{2+}$ channels and catecholamine release with similar potency $(24,26)$. These peptides did not alter high $\mathrm{K}^{+}$-induced ${ }^{45} \mathrm{Ca}^{2+}$ influx via voltagedependent $\mathrm{Ca}^{2+}$ channels, veratridine-induced ${ }^{22} \mathrm{Na}^{+}$influx via voltage-dependent $\mathrm{Na}^{+}$channels, or catecholamine release evoked by histamine, indicating that PAMP20 and PAMP12 have anti-nicotinic properties, but do not act directly on voltage-dependent $\mathrm{Ca}^{2+}$ channels, voltage-dependent $\mathrm{Na}^{+}$channels or histamine receptors $(24,26)$.

Physiological experiments have also shown that the site of action of PAMP20 is nicotinic receptors (56). PAMP20 inhibited both ionic currents and the increase in $\left[\mathrm{Ca}^{2+}\right]_{i}$ induced by nicotinic receptor stimulation. However, PAMP20 did not affect on increase in $\left[\mathrm{Ca}^{2+}\right]_{i}$ induced by the depolarization with high $\mathrm{K}^{+}$. PAMP20 facilitated the desensitization process of the nicotine-induced ion currents. These effects of PAMP20 are not mediated by cAMP, because PAMP did not increase cAMP in the rat adrenal medulla (50) or in bovine adrenal chromaffin cells (unpublished data).

PAMP20 also suppressed catecholamine release from the human adrenal medulla, but the action was different from that observed in bovine adrenal chromaffin cells (52). PAMP20 suppressed catecholamine release caused by activation of voltage-dependent $\mathrm{Ca}^{2+}$ channels by BayK-8644 or by high $\mathrm{K}^{+}$, and by the stimulation of angiotensin II receptors with an $\mathrm{IC}_{50}$ value of $0.1 \mathrm{nmol} / \mathrm{l}$, which was three or four orders lower than the value for suppression of catecholamine release caused by nicotinic receptor stimulation in bovine chromaffin cells or in PC12 cells $(24,57)$. PAMP20 appears to inhibit $\mathrm{Ca}^{2+}$-dependent, agonist-stimulated catecholamine secretion, acting via specific receptors and through a mechanism involving the impairment of $\mathrm{Ca}^{2+}$ influx in humans.

An inhibitory effect of PAMP20 on nicotinic receptor activated catecholamine release has also been observed in in vivo experiments using dogs (55). Catecholamine overflow from the adrenal gland caused by splanchnic nerve stimulation or by acetylcholine injection was suppressed by PAMP20. PAMP20 preferentially suppressed the catecholamine release caused by the nicotinic receptor activation that caused by the muscarinic receptor activation. Thus, PAMP20, but not AM, acts as an inhibitory regulator of adrenal catecholamine release in vivo by acting mainly on nicotinic cholinergic receptors.

PAMP20 also inhibits nicotinic cholinergic receptors in PC12 cells (57). PAMP20 inhibited catecholamine release stimulated by nicotine in a non-competitive manner. PAMP20 failed to inhibit catecholamine release caused by high $\mathrm{K}^{+}, \mathrm{BaCl}_{2}$, calcium ionophore (A23187), purinergic receptor agonist (adenosine 5'-triphosphate, ATP), or alkalinization of the vesicle core (chloroquine). In addition, PAMP completely abolished nicotine-induced influx of ${ }^{45} \mathrm{Ca}^{2+}$ into the cells, but not ${ }^{45} \mathrm{Ca}^{2+}$ influx through voltage-dependent $\mathrm{Ca}^{2+}$ channels caused by high $\mathrm{K}^{+}$. Accordingly, PAMP20 specifically inhibits nicotinic cholinergic receptors in PC12 cells as in bovine adrenal chromaffin cells.

Mahata et al. used PC12 cells to investigate which parts of the structure of PAMP20 were responsible for the inhibition of nicotinic receptors. N-terminal truncation of PAMP20 up to the 12th amino acid did not impair PAMP20 activity, but 


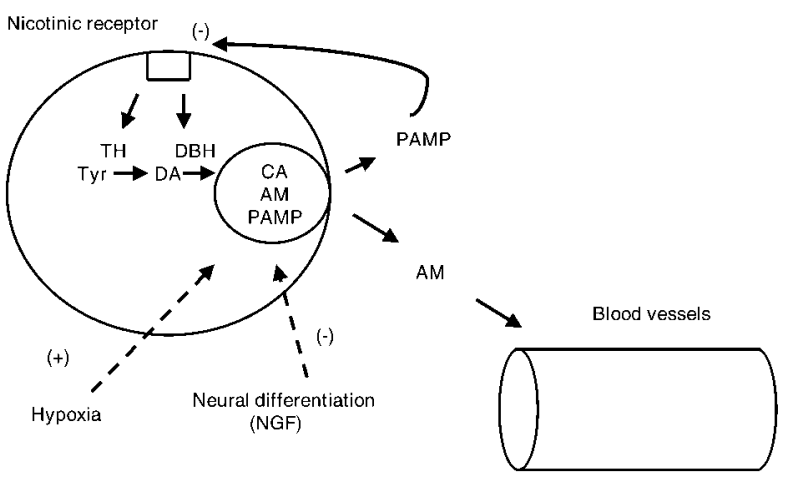

Fig. 3. Schema of the function of AM and PAMP20 family in adrenal chromaffin cells. AM and PAMP2O family $(P A M P)$ are synthesized and released from the chromaffin cell. AM expression increases under hypoxic conditions whereas decreases by neuronal differentiation. PAMP2O family regulates catecholamine synthesis and release as well as the expression of catecholamine synthesizing enzymes by acting on nicotinic cholinergic receptors. AM may be involved in vascular function of adrenal gland by regulating vascular tone and cell growth, differentiation as well as apoptosis of vascular smooth muscle cells and endothelial cells. Details of these mechanisms are described in the text. CA, catecholamine; Tyr, tyrosine; DA, dopamine; TH, tyrosine hydroxylase; DBH, dopamine- $\beta$-hydroxylase; $(+)$, stimulation; ( - ), inhibition.

PAMP[16-20] lost its activity. A peptide without the C-terminal amide structure of PAMP20 showed weak activity, whereas a peptide truncated $\mathrm{C}$-terminal of three amino acids showed no activity. Thus, the essential structures for PAMP action are the $\mathrm{C}$-terminal amide structure and the $\mathrm{C}$-terminal 8 amino acids (WNKWALSR-amide), and the latter region is likely to be an $\alpha$-helical structure (57).

The Gi $\alpha$ subunit of a member of the trimeric G protein family is not involved in the PAMP20-mediated suppression of catecholamine release caused by nicotinic stimulation of PC12 cells and chromaffin cells (57). The PAMP-mediated suppression of catecholamine release caused by nicotinic receptor stimulation was not affected by pertussis toxin (PTX) pre-treatment in undifferentiated PC12 cells that express mainly L-type $\mathrm{Ca}^{2+}$ channels, in PC12 cells differentiated with NGF that express $\mathrm{N}$-type $\mathrm{Ca}^{2+}$ channels (57), or in bovine chromaffin cells (unpublished data).

In addition to their effect on catecholamine release, PAMP20 family peptides also affect catecholamine synthesis. PAMP20 and PAMP12 did not affect basal catecholamine synthesis from tyrosine in cultured bovine adrenal chromaffin cells, but they suppressed the stimulatory effect of catecholamine synthesis caused by nicotinic receptor stimulation with $\mathrm{IC}_{50}$ values of about $1 \mu \mathrm{mol} / 1(24,58)$. PAMP20 and PAMP12 did not affect the basal activity of $\mathrm{TH}$, but suppressed the activation of the enzyme caused by nicotinic stimulation. Thus, PAMP20 and PAMP12 do not exert direct actions on $\mathrm{TH}$, but suppress the $\mathrm{TH}$ activation caused by nicotinic receptor stimulation $(24,58)$.

These peptides of the PAMP20 family are endogenous peptides that regulate not only release and synthesis of catecholamines but also the expression of catecholamine-synthesizing enzymes by acting on nicotinic receptors in an autocrine manner in adrenal chromaffin cells. The expression of mRNAs for the catecholamine-synthesizing enzymes $\mathrm{TH}$ and DBH is increased by the stimulation of nicotinic cholinergic receptors in PC12 cells. PAMP20 but not AM suppressed the nicotine-induced mRNAs for TH and DBH (59).

\section{Conclusion and Perspectives}

AM, PAMP20 and PAMP12 are synthesized, stored and released from adrenal chromaffin cells by regulated as well as constitutive secretory pathways (Fig. 3). The facts that AM expression in chromaffin cells increases under hypoxic conditions and that AM expression in pheochromocytoma decreases during neuronal differentiation indicate the potential pathophysiological roles of AM in chromaffin cells. Peptides of the PAMP20 family act on nicotinic cholinergic receptors on the cell surface and modify cell functions-including catecholamine synthesis, catecholamine release, and the induction of catecholamine synthesizing enzymes-in an autocrine manner. Since the effects of AM on catecholamine release and other chromaffin cell functions were not extensive, the main function of AM may be to regulate local blood flow or remodel the vasculature by regulating the proliferation and apoptosis of vascular smooth muscle cells and endothelial cells.

The relation between high affinity binding sites for AM or PAMP20 and the physiological function in adrenal chromaffin cells remains controversial. The potencies of PAMP20 and PAMP12 in modulating physiological functions, such as by inhibiting catecholamine synthesis, or releasing and inducing production of catecholamine-synthesizing enzymes, are much weaker than their potencies in binding affinity. Finally, further studies will be needed to explore the molecular structure of receptors for PAMP20 family members.

\section{Acknowledgements}

The authors thank Dr. Kazuo Kitamura and colleagues in the Department of Medicine, Miyazaki Medical College, Miyazaki, Japan and the staff in our laboratory for their input and collaboration.

\section{References}

1. Aunis D, Langley K: Physiological aspects of exocytosis in chromaffin cells of the adrenal medulla. Acta Physiol Scand 1999; 167: 89-97.

2. Wada A, Takara H, Izumi F, Kobayashi H, Yanagihara N: Influx of ${ }^{22} \mathrm{Na}$ through acetylcholine receptor-associated $\mathrm{Na}$ channels: relationship between ${ }^{22} \mathrm{Na}$ influx, ${ }^{45} \mathrm{Ca}$ influx and 
secretion of catecholamines in cultured bovine adrenal medulla cells. Neuroscience 1985; 15: 283-292.

3. Ohtsuki H, Morita K, Minami N, Suemitsu T, Tsujimoto A, Dohi T: Involvement of $\mathrm{Ca}^{2+}$ entry and inositol trisphosphate-induced internal $\mathrm{Ca}^{2+}$ mobilization in muscarinic receptor-mediated catecholamine release in dog adrenal chromaffin cells. Neurochem Int 1992; 21: 259-267.

4. Wakade AR, Malhotra RK, Wakade TD, Dixon WR: Simultaneous secretion of catecholamines from the adrenal medulla and of $\left[{ }^{3} \mathrm{H}\right]$ norepinephrine from sympathetic nerves from a single test preparation: different effects of agents on the secretion. Neuroscience 1986; 18: 877-888.

5. Haycock JW, Bennett WF, George RJ, Waymire JC: Multiple site phosphorylation of tyrosine hydroxylase: differential regulation in situ by a 8-bromo-cAMP and acetylcholine. J Biol Chem 1982; 257: 13699-13703.

6. Pelto-Huikko M: Immunocytochemical localization of neuropeptides in the adrenal medulla. J Electron Microsc Tech 1989; 12: 364-379.

7. Winkler H, Westhead E: The molecular organization of adrenal chromaffin granules. Neuroscience 1980; 5: 1803-1823.

8. Simon JP, Bader MF, Aunis D: Secretion from chromaffin cells is controlled by chromogranin A-derived peptides. Proc Natl Acad Sci USA 1988; 85: 1712-1716.

9. Strub JM, Garcia-Sablone P, Lonning K, et al: Processing of chromogranin B in bovine adrenal medulla: identification of secretolytin, the endogenous C-terminal fragment of residues 614-626 with antibacterial activity. Eur J Biochem 1995; 229: 356-368.

10. Glombik MM, Kromer A, Salm T, Huttner WB, Gerdes $\mathrm{HH}$ : The disulfide-bonded loop of chromogranin B mediates membrane binding and directs sorting from the transGolgi network to secretory granules. EMBO J 1999; 18: 1059-1070.

11. Gasparri A, Sidoli A, Sanchez LP, et al: Chromogranin A fragments modulate cell adhesion: identification and characterization of a pro-adhesive domain. J Biol Chem 1997; 272: 20835-20843.

12. Kitamura $\mathrm{K}$, Kangawa $\mathrm{K}$, Kawamoto $\mathrm{M}$, et al: Adrenomedullin: a novel hypotensive peptide isolated from human pheochromocytoma. Biochem Biophys Res Commun 1993; 192: 553-560.

13. Ishiyama Y, Kitamura K, Kato J, Sakata J, Kangawa K, Eto T: Changes in cardiac adrenomedullin concentration in renovascular hypertensive rats. Hypertens Res 1997; 20: 113-117.

14. Nishikimi T, Yoshihara F, Morimoto A, et al: Relationship between left ventricular geometry and natriuretic peptide levels in essential hypertension. Hypertension 1996; 28: 22-30.

15. Kitamura K, Kangawa K, Ishiyama Y, et al: Identification and hypotensive activity of proadrenomedullin N-terminal 20 peptide (PAMP). FEBS Lett 1994; 351: 35-37.

16. Nuki C, Kawasaki H, Kitamura K, et al: Vasodilator effect of adrenomedullin and calcitonin gene-related peptide receptors in rat mesenteric vascular beds. Biochem Biophys Res Commun 1993; 196: 245-251.

17. Shimosawa T, Ito Y, Ando K, Kitamura K, Kangawa K, Fujita T: Proadrenomedullin $\mathrm{NH}_{2}$-terminal 20 peptide, a new product of the adrenomedullin gene, inhibits norepinephrine overflow from nerve endings. J Clin Invest 1995; 96: $1672-1676$.

18. Asada Y, Hara S, Marutsuka K, et al: Novel distribution of adrenomedullin-immunoreactive cells in human tissues. Histochem Cell Biol 1999; 112: 185-191.

19. Ichiki Y, Kitamura K, Kangawa K, Kawamoto M, Matsuo $\mathrm{H}$, Eto T: Distribution and characterization of immunoreactive adrenomedullin in human tissue and plasma. FEBS Lett 1994; 338: 6-10.

20. Sakata J, Shimokubo T, Kitamura K, et al: Distribution and characterization of immunoreactive rat adrenomedullin in tissue and plasma. FEBS Lett 1994; 352: 105-108.

21. Washimine H, Asada Y, Kitamura K, et al: Immunohistochemical identification of adrenomedullin in human, rat, and porcine tissue. Histochem Cell Biol 1995; 103: 251-254.

22. Washimine H, Kitamura K, Ichiki Y, et al: Immunoreactive proadrenomedullin $\mathrm{N}$-terminal 20 peptide in human tissue, plasma and urine. Biochem Biophys Res Commun 1994; 202: $1081-1087$.

23. Kuwasako K, Kitamura K, Ichiki Y, et al: Human proadrenomedullin N-terminal 20 peptide in pheochromocytoma and normal adrenal medulla. Biochem Biophys Res Commun 1995; 211: 694-699.

24. Kobayashi H, Yamamoto R, Kitamura K, et al: Selective inhibition of nicotinic cholinergic receptors by proadrenomedullin N-terminal 12 peptide in bovine adrenal chromaffin cells. Brain Res Mol Brain Res 2001; 87: 175-183.

25. Kuwasako K, Kitamura K, Ishiyama Y, et al: Purification and characterization of PAMP-12 (PAMP[9-20]) in porcine adrenal medulla as a major endogenous biologically active peptide. FEBS Lett 1997; 414: 105-110.

26. Katoh F, Kitamura K, Niina H, et al: Proadrenomedullin Nterminal 20 peptide (PAMP), an endogenous anticholinergic peptide: its exocytotic secretion and inhibition of catecholamine secretion in adrenal medulla. J Neurochem 1995; 64: 459-461.

27. Katoh F, Niina $\mathrm{H}$, Kitamura $\mathrm{K}$, et al: $\mathrm{Ca}^{2+}$-dependent cosecretion of adrenomedullin and catecholamines mediated by nicotinic receptors in bovine cultured adrenal medullary cells. FEBS Lett 1994; 348: 61-64.

28. Kobayashi H, Yamamoto R, Kitamura K, et al: Cyclic AMP-dependent synthesis and release of adrenomedullin and proadrenomedullin $\mathrm{N}$-terminal 20 peptide in cultured bovine adrenal chromaffin cells. Eur J Biochem 1999; 263: 702-708.

29. Nishikimi T, Kitamura K, Saito Y, et al: Clinical studies on the sites of production and clearance of circulating adrenomedullin in human subjects. Hypertension 1994; 24 600-604.

30. Ehlenz K, Koch B, Preuss P, Simon B, Koop I, Lang RE: High levels of circulating adrenomedullin in severe illness: correlation with C-reactive protein and evidence against the adrenal medulla as site of origin. Exp Clin Endocrinol Diabetes 1997; 105: 156-162.

31. Sugo S, Minamino N, Shoji H, et al: Production and secretion of adrenomedullin from vascular smooth muscle cells: augmented production by tumor necrosis factor- $\alpha$. Biochem Biophys Res Commun 1994; 203: 719-726. 
32. Sugo S, Minamino N, Kangawa K, et al: Endothelial cells actively synthesize and secrete adrenomedullin. Biochem Biophys Res Commun 1994; 201: 1160-1166.

33. Kis B, Kaiya H, Nishi R, et al: Cerebral endothelial cells are a major source of adrenomedullin. $J$ Neuroendocrinol 2002; 14: 283-293.

34. Guillemin K, Krasnow MA: The hypoxic response: huffing and HIFing. Cell 1997; 89: 9-12.

35. Garayoa M, Martinez A, Lee S, et al: Hypoxia-inducible factor-1 (HIF-1) up-regulates adrenomedullin expression in human tumor cell lines during oxygen deprivation: a possible promotion mechanism of carcinogenesis. Mol Endocrinol 2000; 14: 848-862.

36. He H, Bessho H, Fujisawa Y, et al: Effects of a synthetic rat adrenomedullin on regional hemodynamics in rats. Eur J Pharmacol 1995; 273: 209-214.

37. Mazzocchi G, Musajo F, Neri G, Gottardo G, Nussdorfer GG: Adrenomedullin stimulates steroid secretion by the isolated perfused rat adrenal gland in situ: comparison with calcitonin gene-related peptide effects. Peptides 1996; 17: 853-857.

38. Wang X, Yue TL, Barone FC, et al: Discovery of adrenomedullin in rat ischemic cortex and evidence for its role in exacerbating focal brain ischemic damage. Proc Natl Acad Sci US A 1995; 92: 11480-11484.

39. Kobayashi $\mathrm{H}$, Yanagita $\mathrm{T}$, Yokoo $\mathrm{H}$, Wada A: Adrenomedullin and proadrenomedullin N-terminal 20 peptide (PAMP) in adrenal chromaffin cells. Peptides 2001; 22: 1895-1901.

40. Owji AA, Smith DM, Coppock HA, et al: An abundant and specific binding site for the novel vasodilator adrenomedullin in the rat. Endocrinology 1995; 136: 2127-2134.

41. Mazzocchi G, Albertin G, Andreis PG, et al: Distribution, functional role, and signaling mechanism of adrenomedullin receptors in the rat adrenal gland. Peptides 1999; 20: 1479-1487.

42. Renshaw D, Thomson LM, Michael GJ, Carroll M, Kapas S, Hinson JP: Adrenomedullin receptor is found exclusively in noradrenaline-secreting cells of the rat adrenal medulla. J Neurochem 2000; 74: 1766-1772.

43. Kapas S, Catt KJ, Clark AJ: Cloning and expression of cDNA encoding a rat adrenomedullin receptor. $J$ Biol Chem 1995; 270: 25344-25347.

44. Kapas S, Clark AJ: Identification of an orphan receptor gene as a type 1 calcitonin gene-related peptide receptor. Biochem Biophys Res Commun 1995; 217: 832-838.

45. McLatchie LM, Fraser NJ, Main MJ, et al: RAMPs regulate the transport and ligand specificity of the calcitonin-receptor-like receptor. Nature 1998; 393: 333-339.

46. Chakravarty P, Suthar TP, Coppock HA, et al: CGRP and adrenomedullin binding correlates with transcript levels for calcitonin receptor-like receptor (CRLR) and receptor ac- tivity modifying proteins (RAMPs) in rat tissues. $\mathrm{Br} J$ Pharmacol 2000; 130: 189-195.

47. Kennedy SP, Sun D, Oleynek JJ, Hoth CF, Kong J, Hill RJ: Expression of the rat adrenomedullin receptor or a putative human adrenomedullin receptor does not correlate with adrenomedullin binding or functional response. Biochem Biophys Res Commun 1998; 244: 832-837.

48. Mulder H, Ahren B, Karlsson S, Sundler F: Adrenomedullin: localization in the gastrointestinal tract and effects on insulin secretion. Regul Pept 1996; 62: 107-112.

49. Iwasaki H, Hirata Y, Iwashina M, Sato K, Marumo F: Specific binding sites for proadrenomedullin N-terminal 20 peptide (PAMP) in the rat. Endocrinology 1996; 137: 3045-3050.

50. Hinson JP, Hagi-Pavli E, Thomson LM, Kapas S: Proadrenomedullin N-terminal 20-peptide (PAMP) receptors and signal transduction in the rat adrenal gland. Life Sci 1998; 62: $439-443$

51. Andreis PG, Tortorella C, Mazzocchi G, Nussdorfer GG: Proadrenomedullin N-terminal 20 peptide inhibits aldosterone secretion of human adrenocortical and Conn's adenoma cells: comparison with adrenomedullin effect. J Clin Endocrinol Metab 1998; 83: 253-257.

52. Belloni AS, Rossi GP, Andreis PG, et al: Proadrenomedullin N-terminal 20 peptide (PAMP), acting through PAMP(1220)-sensitive receptors, inhibits $\mathrm{Ca}^{2+}$-dependent, agoniststimulated secretion of human adrenal glands. Hypertension 1999; 33: 1185-1189.

53. Andreis PG, Neri G, Prayer-Galetti T, et al: Effects of adrenomedullin on the human adrenal glands: an in vitro study. J Clin Endocrinol Metab 1997; 82: 1167-1170.

54. Houchi H, Yoshizumi M, Shono M, Ishimura Y, Ohuchi T, Oka M: Adrenomedullin stimulates calcium efflux from adrenal chromaffin cells in culture: possible involvement of an $\mathrm{Na}^{+} / \mathrm{Ca}^{2+}$ exchange mechanism. Life Sci 1996; 58: 35-40.

55. Masada K, Nagayama T, Hosokawa A, et al: Effects of adrenomedullin and PAMP on adrenal catecholamine release in dogs. Am J Physiol 1999; 276: R1118-R1124.

56. Nagatomo $\mathrm{T}$, Shibuya I, Kabashima N, et al: Proadrenomedullin N-terminal 20 peptide (PAMP) reduces inward currents and $\mathrm{Ca}^{2+}$ rises induced by nicotine in bovine adrenal medullary cells. Life Sci 1996; 59: 1723-1730.

57. Mahata M, Mahata SK, Parmer RJ, O’Connor DT: Proadrenomedullin $\mathrm{N}$-terminal 20 peptide: minimal active region to regulate nicotinic receptors. Hypertension 1998; 32: 907-916.

58. Niina H, Kobayashi H, Kitamura K, Katoh F, Eto T, Wada A: Inhibition of catecholamine synthesis by proadrenomedullin $\mathrm{N}$-terminal 20 peptide in cultured bovine adrenal medullary cells. Eur J Pharmacol 1995; 286: 95-97.

59. Takekoshi K, Isobe K, Nomura F, Motooka M, Nanmoku T, Nakai T: Effects of PAMP on mRNAs coding for catecholamine-synthesizing enzymes in PC12 cells. Life Sci 1999; 65: 771-781. 